\title{
On the Anthropocene formalization and the proposal by the Anthropocene Working Group
}

\author{
C. Soriano \\ Institute of Earth Sciences Jaume Almera, CSIC \\ C/ Lluis Solé Sabaris s/n, Barcelona 08028, Spain \\ Email: csoriano@ictja.csic.es
}

\begin{abstract}
In the coming years the Anthropocene will be likely submitted to formalization by the Anthropocene Working Group as a chronostratigraphic unit of the Geologic Time Scale. This has generated an increasing debate among detractors and defenders of its formalization in general, and of the proposal by the Anthropocene Working Group in particular. Here, the main issues regarding the Geologic Time Scale and the rules to formalize units, the empirical data supporting the Anthropocene formalization and the critiques to formalize it are critically reviewed. The procedure to formalize the Anthropocene is not dissimilar from those of the other units of the Geologic Time Scale and has been essentially based on stratigraphic and geologic criteria. Following the recommendation of the Anthropocene Working Group and based on the empirical evidence on the Anthropocene as it is expressed in strata and, more important, on the immanent and structural link between the Anthropocene and the reproduction of capital, it is proposed to define Capitalian as a Stage of the Anthropocene Epoch. In this way, a truly comprehensive understanding of the Earth history is obtained, which comprises the ultimate causes of the ongoing planetary transformation and its stratigraphic expression.
\end{abstract}

\section{INTRODUCTION}

The Anthropocene is an ongoing and profound transformation of many of the terrestrial geospheres, including the atmosphere, biosphere, hydrosphere and lithosphere. As a logical result of the research undertaken on the planetary-scale change of the Anthropocene, Earth scientists have wondered if such a global change is being registered in the stratigraphic record. The affirmative response to this question has lead geologists to consider the formalization of the Anthropocene as a new unit of the International Chronostratigraphic Chart (ICC), which serves as the basis for the Geologic Time Scale (GTS) (Waters et al., 2016, 2018; Zalasiewicz et al., 2017). The formalization of the Anthropocene and the proposal launched by the Anthropocene Working Group (AWG) to formalize it as a new Epoch of the ICC have generated an increasing debate and several possibilities regarding formalization are still open, among them that the AWG proposal is rejected by the committees responsible for the decision to include it as new unit of the ICC.

In this contribution, the main issues regarding formalization of chronostratigraphic units in the ICC/GTS and the AWG proposal to formalize the Anthropocene are critically reviewed. To this purpose, the empirical evidence supporting the Anthropocene change emphasizing its specific character when compared to similar changes occurred during the Earth history and human history is shortly revisited. Then, the qualitative and quantitative expression of the Anthropocene transformation in the geologic and stratigraphic record is highlighted. The 
significance of the ICC and GTS as tools aimed to represent our current understanding of the history of the Earth and their prospects in this regard are remarked. Some of the main criticisms to the Anthropocene formalization and to the AWG proposal are addressed focussing on the implications regarding social organization of humans and on the epistemological requirements of the Anthropocene issue. Finally, some conclusions regarding the formalization of chronostratigraphic units are extracted and a Stage of the potential Anthropocene Epoch is suggested in order to complement the proposal by the AWG.

\section{EMPIRICAL EVIDENCE OF THE ANTHRO- POCENE}

The mounting empirical evidence built up by Anthropocene studies in nearly twenty years of research leaves little doubt, if any, about the anthropogenic nature of the Earth transformation and there is only some dispute about the magnitude of the planetary change and, particularly, about the different approaches to face it. A striking feature of the Anthropocene change is the rate at which the different physical, chemical and biological processes occur. For example, the rate of vertebrate extinction directly induced by human action exceeds that of the major mass extinction episodes in the Earth history known from the stratigraphic record (Barnosky et al., 2011; Ceballos et al., 2015). Only the Cretaceous-Paleogene extinction at $\sim 66 \mathrm{My}$ due to the abrupt climate change triggered by a large bolide impact on Earth shows a higher extinction rate. Nevertheless, the role played by climatemodifying gases released during Deccan Traps volcanism at about the same age of the bolide impact is being debated (Sprain et al., 2019). Hence, the fast extinction rate at the $\mathrm{K}-\mathrm{Pg}$ boundary could be related to multiple factors and not just to a single factor as it is the extinction rate due to human action in the Anthropocene. Biodiversity loss, homogenization of the world's biota and appearance of invasive species through deliberate or accidental human actions occur at unprecedented rates in human history since the last century (Steffen et al., 2016; Waters et al., 2018). Greenhouse gases and in particular $\mathrm{CO}_{2}$ are being released through the atmosphere by human activity at unprecedented rates in the last 66 million years of the Earth history. The anthropogenic release of $\mathrm{CO}_{2}$ is 10 times higher than a well-known event occurred 56 million years ago at the Paleocene-Eocene boundary and 100 times higher than the $\mathrm{CO}_{2}$ release during the Late Pleistocene to Early Holocene, which is considered a fast release in geological terms (Steffen et al., 2016; Waters et al., 2108). Global surface temperature, tropical forest loss, desertification, ocean acidification, solid particle concentration in the atmosphere, plastic particle concentration in the marine realm, in summary, an everyday increasing number of data document the anthropogenic impact on Earth (see Delasalla and Goldstein, 2018; Steffen et al., 2015; and references herein for extended treatments of these indicators). Most of these data indicate that the processes involved in the Anthropocene change occur at accelerated rates and in a nonlinear way (Oldfield and Steffen, 2014; Rockström et al., 2009).

Considered as a whole, the empirical evidence on the Anthropocene change suggests that the Earth is now operating in a no analogue state with regard to the prevailing conditions in the Holocene Epoch. The empirical indicators of the Anthropocene change leave little doubt on the fact that the ongoing planetary transformation is restricted to the last 300-200 years of human history. Hence, the Earth is now operating in a no analogue state in human history too. Actually, the more the scientific research on the Anthropocene proceeds, the more evidence is collected indicating that the Earth's transformation since the last 300-200 years has reached an unprecedented magnitude in human history. Given the accelerated rates and the feedback mechanisms among the different processes involved, the planetary change is itself accelerated and increases its magnitude with time. Therefore, the difference between the anthropogenic impact in the last 300-200 years and any previous anthropogenic impact is a matter of scale (Zalasiewicz et al., 2019). Put in simple words, whatever it was the anthropogenic change on the Earth before the last 300200 years it was barely anything in terms of the magnitude and the rate when compared to the Anthropocene change. The evolution of world population is the best empirical indicator illustrating the former dimensional difference because it synthesizes all other indicators measuring the anthropogenic impact on Earth (Fig. 1). The evidence is clear: whatever important the innovations and advances made by humans were during the past $10^{4}$ years human population did not increase above 0.5 billion people, while since 1700 to 2019 human population has increased from 0.6 to 7.7 billion people. Accordingly, the anthropogenic Earth's transformation during Anthropocene times occurs at a significantly higher scale with respect to that of the pre-Anthropocene times.

The human impact on the Earth is certainly related to the number of humans living on the planet but the relation between human population and human impact is not just direct and proportional. Rather, it depends on how humans produce, distribute, exchange and consume their means of life. That is, it depends on how humans are socially and economically organized to reproduce themselves as a collective social being that settles a particular interaction or metabolic relation with the rest of the planet, a metabolic relation that depends, precisely, on the kind of social and economic organization. Ten 


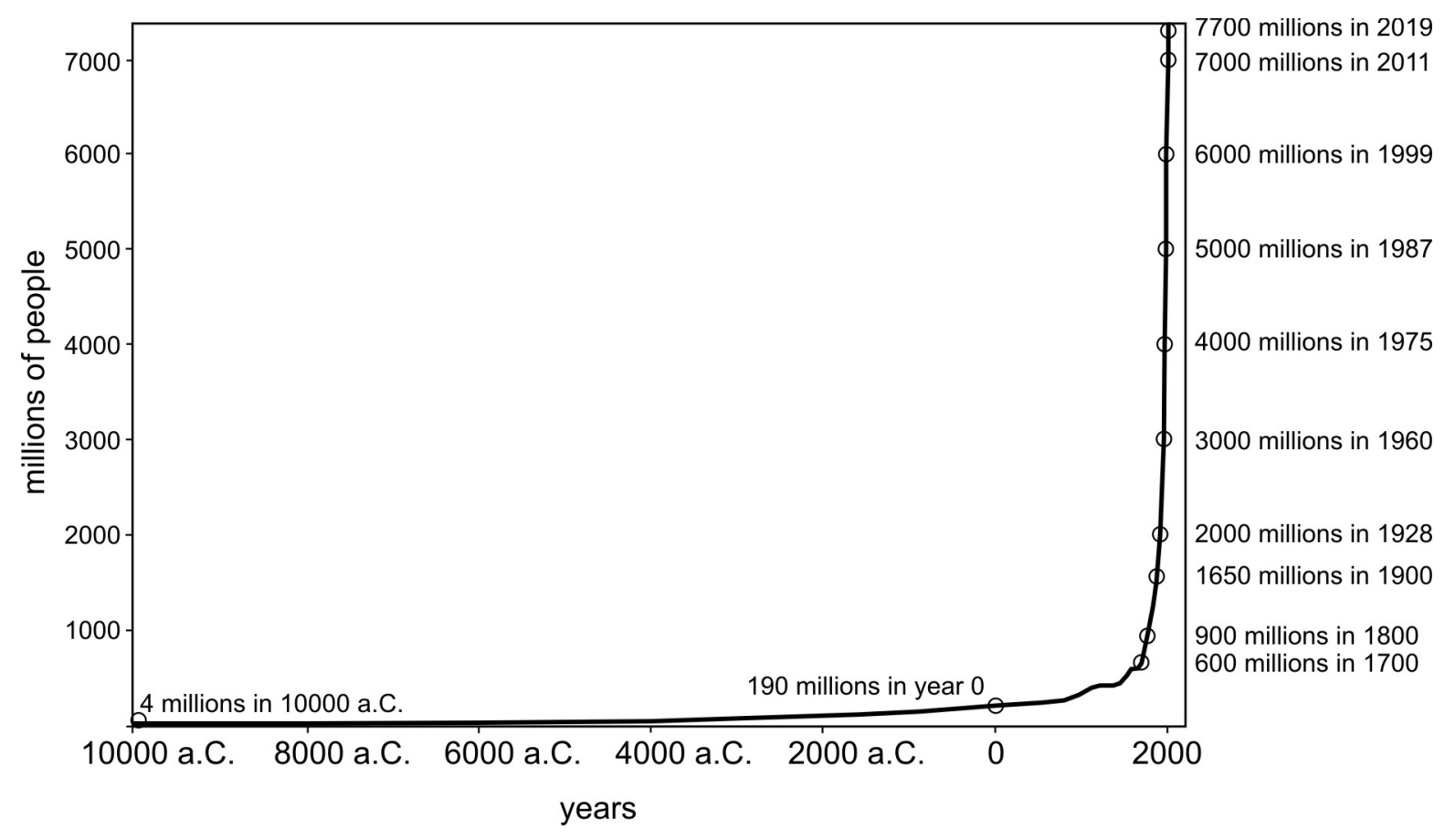

FIGURE 1. Evolution of the world population during the last 12000 years (modified from Roser et al., 2019).

humans will likely have lower impact on Earth than a thousand humans and here humans can be substituted by beavers, ants or dinosaurs. However, ten humans organized in a particular socioeconomic form may have more impact on Earth than a thousand humans organized in a different socioeconomic form and here humans cannot be substituted by any other living or past species. Hence, a comprehensive understanding of the Anthropocene cannot be untangled from the study of the different forms of social organization through history. In particular, the current socioeconomic form, which has governed human history during the last centuries, has to be analysed from a critical perspective if a scientific understanding of the Anthropocene is pursued. Otherwise, understanding the Anthropocene becomes a merely descriptive exercise in which historical events are empirically correlated to specific indicators of the Anthropocene and, on this basis, not any long-standing solution for the Anthropocene threat can be proposed.

The empirical indicators of the Anthropocene change as synthesized in the evolution of human population provide clear evidence on the quantitative and abrupt departure of human impact on Earth since the last 300-200 years. This departure is inherently linked to a historical form of human social organization that has specific qualitative differences with regard to any other form in human history, from which the quantitative departure of the Anthropocene change is derived (Soriano, 2018a). The correlation between Anthropocene change and the capitalist mode of social production based on the reproduction of capital is here inferred from empirical evidence and not from any political, ideological nor any sort of morality viewpoint. In addition, the structural link between the capitalist mode of production based on the reproduction of capital and the Anthropocene transformation has been demonstrated by unfolding the internal contradictions of this production mode (Angus, 2016; Chen, 2017; Malm, 2016; Soriano, 2018a). Doing this implies a scientific research based on dialectical logic by opposition to a positivist and idealistic view, which pretends that the reproduction of capital is eternal and operates without contradictions or that the contradictions can be resolved within the limits of capital reproduction, a view that does not correspond to the objective reality. It is beyond the scope of this contribution to delve into topics such as dialectics, logic, positivism and idealism, yet it is worth to remark that the immanent link between the reproduction of capital and the Anthropocene transformation has been rigorously and scientifically deduced and, on this basis, the empirical evidence of the Anthropocene constitutes the form in which the capitalist mode of production manifests in the terrestrial geospheres. Hence, if the Anthropocene change has any stratigraphic signal suitable to be formalized in the ICC it is clear that such geologic record cannot be located in strata much older than 300-200 years, for by that time the anthropogenic transformation of the Earth was not about the scale shown by the empirical data collected for the Anthropocene (Zalasiewicz et al., 2019). 


\section{GEOLOGIC AND STRATIGRAPHIC FORM OF THE ANTHROPOCENE}

The imprint of human activity in strata is well known from many disciplines like archaeology, palaeontology, anthropology, biology, geology and history. Hence, a geologic form of anthropogenic origin is well established and, in terms of the Anthropocene formalization, the question is whether the stratigraphic form corresponding to the Anthropocene is qualitatively and quantitatively different from the imprint of human activity in strata in pre-Anthropocene times. The profound landscape transformation experienced during the last 300-200 years has no analogue in human history and given the rate at which this transformation occurs it is doubtful that any analogue in the Earth's history can be found. Most of the Earth's surface change we see today is the result of human action during the last century. Since the Anthropocene term was launched in 2000, an increasing number of stratigraphic proxies recorded in an increasing number of palaeoenvironmental archives are being discovered (Waters et al., 2018). They document the Anthropocene transformation recorded in strata that corresponds to the complex socioeconomic and global organization of capitalism and it is difficult to envisage any analogue in human history in terms of the quantity and variety of key markers and deposits involved. Waters et al. (2018) provide a review of stratigraphic markers and palaeoenvironamental settings and facies that might host a Global Boundary Stratotype Section and Point (GSSP) on which the base of the Anthropocene may be placed and it may be globally correlated following the ICC requirements.

Based on the empirical evidence of the Anthropocene transformation and on its expression as geomorphologic forms and stratigraphic records, it must be concluded that the Anthropocene is neither an academic invention, nor an issue of pop culture or a political statement (Autin and Holbrock, 2012a; Finney and Edwards, 2016; Visconti, 2014). On the contrary, it is the objective reality of the human activity on Earth imprinted in the rocks and, in particular, of the kind of human activity undertaken under the socioeconomic laws of the capitalist mode of production (Soriano, 2018a). Therefore, the issue to be analysed is if the stratal expression of the Anthropocene change meets the requirements of the ICC to be formalized as a new chronostratigraphic unit and, eventually, what is the most suitable hierarchical position. However, when analysing the suitability of proxies and depositional facies to host a candidate GSSP for the Anthropocene unit, the physical and chemical processes involved cannot be fully untangled from socioeconomic processes. First, because most depositional settings are already altered at about the same order of magnitude than the Anthropocene transformation and, second, because most of the proxies considered are directly and indirectly related to the cycle of capital reproduction based on the production of commodities and to the social pressure against the undesired effects of many waste materials of the capitalist production mode. This is equivalent to say that occurrences of proxies in depositional environments that can be candidates to host a GSSP for the Anthropocene are related to class struggle too. Accumulation of lead in bioherms, lake sediments and ice is related to the history of production of leaded and unleaded gasoline and to the different national and international legislations on the subject; accumulation of chlorinated pesticides like DDT in lake sediments and marine anoxic basins increased worldwide since 1950s and declined after its ban; spheroidal carbonaceous particles resulting from fossil fuel combustion are recorded in strata since the XIX century (Waters et al., 2018) but such stratal record might decline if a fossil fuel transition occurs. All these are examples of commodities produced for profit and not for the use value inherent to any commodity, whose particular histories depend on the historical evolution of the cycles of capital reproduction and of the national and international legislations aimed to reconcile the interest of capital with the social pressure. Essentially, they are phenomenic expressions of the internal contradictions of the capitalist production mode.

\section{THE INTERNATIONAL CHRONOSTRATI- GRAPHIC CHART AND THE GEOLOGIC TIME SCALE}

The ICC can be understood as a composite stratigraphic succession of the Earth upon which the history of the Earth is referred in terms of the processes and events registered in rocks. An accurate understanding of the Earth history requires the chronostratigraphic units of the ICC to be anchored to a linear time scale as precise as possible. Such a chronometric scale is obtained independently of the chronostratigraphic succession of the ICC mainly by astronomical tuning of continuous sedimentary strata and by absolute radiometric dating of discrete rocks in the stratigraphic record. The chronostratigraphic scale and the chronometric scale are calibrated using different fitting techniques to obtain a GTS to which the Earth scientists can be referred. The GTS is intended to be "the tool 'par excellence' of the geological trade" (Gradstein, 2012, p. 1, emphasis in the original); it is aimed to provide a standardized instrument to Earth scientists of many different subdisciplines and hence has an eminent practical and pragmatic character. Ideally, the GTS should provide a globally-correlated continuous stratigraphic record of the Earth scientists with accurate age estimation so that orogenic processes, greenhouse episodes, mass extinctions, glaciations and many other events in the Earth history -like the human action in the Anthropocene- can be related to 
specific chronostratigraphic units. Therefore, conception of the ICC and the GTS already has since the beginning the integral and holistic approach claimed to be a distinctive feature of modern Earth System science (Steffen et al., 2016).

The GTS is under continuous revision and evolves in accordance with our understanding of the Earth history. Improvements in dating techniques, analytical geochemical methods, the knowledge of depositional systems, fossil evolution and the geomagnetic field among many others have conditioned the GTS configuration through history. Initially, the stages of the ICC were characterized by the approximate position and duration of their stratotypes, whose definition was usually based on their fossil content and, sometimes, were merely facies types with a local distribution. GSSPs were conceived to solve the inherent limitations of stage stratotypes, favouring global correlation and continuous stratigraphic record. To this purpose GSSPs define boundaries between chronostratigraphic units and they must be recognized outside the type locality where they are defined, so correlation to other events in the Earth history is possible. Besides, GSSPs must be placed within stratigraphic intervals of continuous sedimentation, so the composite stratigraphic succession of the Earth is as continuous as possible. Based on these requisites, an ideal GSSP should be placed in a low latitude location suitable for cyclostratigraphy and astronomical tuning, consists of marine cyclic sediments continuously deposited and interbedded with volcanic tephra layers suitable for absolute dating, be fossiliferous and with distinct geochemical signatures and magnetostratigraphy to provide a global correlation and, finally, the GSSP horizon should be preferably dated or bracketed between dateable horizons (Gradstein and Ogg, 2012). Although the International Commission on Stratigraphy settles standardize rules for the chronostratigraphic units of the ICC and for GSSP definition, it should be reminded that every unit and GSSP of the GTS has its own particularities and quite often these rules have been relaxed when accepting new units and GSSP boundaries or modifying previous ones. For example, ice cores hosting GSSP boundaries for the Holocene and for its internal subdivisions constitute exceptions in the GTS, because most GSSPs are located in rocks. Equally, isotopic events and Milankovich cycles have been incorporated only very recently as primary markers to define boundaries in GSSPs and, traditionally, most boundaries of the GTS were based on palaeontological changes.

Chronostratigraphic units defined by GSSPs have, however, their own limitations, particularly, that the stratigraphic content of units is poorly defined and this may hinder global correlation. Chronostratigraphic units defined both by their GSSP boundaries and their stratotype content, in which sedimentary record is continuous, multiple correlation markers are identified across unit and unit boundaries and a chronometric control as accurate as possible is obtained across unit and unit boundaries would be desirable for global correlation. In this way, Earth maps of chronostratigraphic units at the desired scales substage, stage, epoch, period- reflecting differences in stratotype content could be produced along the linear time of the Earth history. At present, the chronostratigraphic units of the GTS have a dual time-rock nomenclature (Early-Lower, Age-Stage, Epoch-Series and so on), that is unpractical in many instances (Gradstein and Ogg, 2012; Harland et al., 1990; Zalasiewicz et al., 2017). Besides, any rock of the stratigraphic record is emplaced within a particular time interval and hence it is by definition a time-rock unit. Astronomical tuning and high precision cyclostratigraphy of continuous sedimentary strata allow combining unit stratotypes and boundary stratotypes so that chronostratigraphic units can be defined both by their boundaries and their content and the dual nomenclature of GTS units can be overcome (see Hilgen et al., 2006 and examples for the Zanclean and Piacenzian stages of the Pliocene in Italy and for the Danian and Selandian stages of the Paleocene in Spain in Gradstein et al., 2012). This is certainly one of the main near-future challenges of the GTS.

\section{CRITICISMS TO THE ANTHROPOCENE FORMALIZATION AND TO THE PROPOSAL BY THE ANTHROPOCENE WORKING GROUP}

The AWG proposal to formalize the Anthropocene as an Epoch of the ICC/GTS has been exposed and refined along the last years partly in response to criticisms of scientists from the fields of natural and social sciences. As already acknowledged by the AWG members, such criticisms form part of the usual scientific discussion and contribute to ameliorate the AWG proposal in particular and the ICC and GTS in a broader sense (Zalasiewicz et al., 2017). The AWG has addressed the critiques received in the form of comments to published papers and, more extensively, in specific publications (Waters et al., 2016; Zalasiewicz et al., 2012, 2016, 2017, 2018, 2019). Overall, the AWG has responded to critiques in a detailed, rigorous, scientific and geologically sounded way. Issues like the preservation potential, the global correlation potential and the short time span encompassed if a mid- $20^{\text {th }}$ century base for the Anthropocene is approved, together with the convenience or not that chronostratigraphic units are linked to major Earth changes and etymological objections to formalization have been already addressed (see Zalasiewicz et al., 2017). Here, the focus is on those issues allowing a view different than that of the AWG and aimed to broaden the Anthropocene topic beyond-but in relation-to Earth System sciences and geology, a broadening that is claimed by the topic itself. 
Some critics of the Anthropocene formalization seem to have misunderstood the nature of the ICC/GTS. These are instruments that represent the history of Earth and are aimed to facilitate communication, primarily among scientists but not only. Construction of these tools is certainly based on a scientific understanding of natural history but also on practical purposes. Such representations of the Earth history cannot be mistaken by the scientific understanding of the Earth history itself nor can the rules of the ICC/GTS be mistaken by scientific rules. The practical character of these representations varies depending on the scientific disciplines involved, their goals, their techniques and other aspects. Practicality is a non-scientific issue since different disciplines may want to favour particular aspects of the ICC/ GTS according to, for example, their particular targets. For this reason an agreement is required, but any agreement is by definition non-scientific but political. Besides, it should not have to be reminded that any decision of any committee regarding formalization relies on the subjective perception of individuals about practicality, accomplishment of rules, etc., which is a political issue too.

One of the major concerns raised by critics of the Anthropocene formalization is about its utility, not just in stratigraphy and geology but also in other scientific disciplines such as anthropology, archaeology and, more widely, in humanities (Autin and Holbrock, 2012a; Braje, 2016; Finney and Edwards, 2016; Klein, 2015; Walker et al., 2015). With regard to geology, the debate focuses on the usefulness of the Anthropocene to the present configuration of the ICC in practical terms. Yet it is true that the ICC is an agreed convention with a preeminent instrumental character, it is not less true that this tool is essentially aimed at the understanding of the Earth history. To this purpose, the ICC is combined with a chronometric scale to construct the GTS, the standardize time-framework to which the events of the Earth history are referred. The Anthropocene transformation is an objective reality with objective geologic and stratigraphic signatures that mark a qualitatively and quantitatively departure with respect to the underlying strata. Given that the Anthropocene formalization in the ICC and the GTS allows a better understanding of the ongoing planetary-scale transformation of the Earth as it is expressed in the stratigraphic record, there is no reason for not to formalize it.

The fact that this major change on Earth is the result of a production mode characterized by the reproduction of capital and that the establishment of such a mode of production is a diachronous process -as all geological processes indeed-initiated before the starting date proposed for the Anthropocene by the AWG is completely irrelevant here, for the reproduction of capital understood as the essentials of the Anthropocene crisis and its geologic expression in strata does not have necessarily to coincide (Soriano, 2018a). Yet the mid- $20^{\text {th }}$ century starting date for the Anthropocene as proposed by Waters et al. (2018) roughly coincides with the golden age of capitalism worldwide, including countries of the socialist block that reproduced socially following the productivist scheme of capitalism and in which capital reproduction based on labour exploitation was not removed (Mészáros, 2008). Therefore, the formalization of the Anthropocene as proposed by the AWG provides a standardized chronostratigraphic framework to understand the ongoing Earth transformation in toto, which for the case of the Anthropocene implies to consider the natural and socioeconomic mechanisms involved, together with their mutual interactions. It is irrelevant whether geologists, stratigraphers, philosophers, politicians and other scientific disciplines like it or not, such an integral understanding is an epistemological demand of the Anthropocene subject, of the Anthropocene change and its stratal expression. The AWG proposal allows understanding the fundamental cause underlying the Anthropocene transformation, namely, the capitalist production mode based on the reproduction of capital, as it is clearly expressed in the geological record. A formalization based on such comprehensive understanding of the Anthropocene crisis automatically excludes the geologic record of pre-capitalist production modes as stratigraphic markers and sections of the Anthropocene. Therefore, the AWG proposal does not dilute the ongoing Earth crisis throughout human history and distributes the responsibility equally across all socio-economic groups as suggested by some authors (e.g. Braje, 2016; Malm and Hornborg, 2014). On the contrary, it clearly identifies perhaps inadvertently to the AWG- the objective and real causes underlying the Earth transformation, provided the fundamentals of the capitalist mode of production are properly studied and understood.

Some critiques to the Anthropocene formalization stress that the socioeconomic features implicit in the issue are not a geological matter, that the concept of the Anthropocene comes from outside the stratigraphy and that a supposed inductive character of geological sciences and of sciences in general is violated favouring deductive analysis (Autin and Holbrock, 2012b; Finney and Edwards, 2016; Rull, 2017, 2018). Although the ICC and the GTS have been constructed primarily by Earth scientists, it should not have to be reminded that none of these instruments are the private property of Earth sciences nor that any scientific discipline operates disconnected from socio-historical determinations. Insofar as the Earth transformation and its manifestation in strata is driven by human action carried out under the laws of capital reproduction, a comprehensive understanding of the Anthropocene explicitly requires that socioeconomic processes in general and the socioeconomic processes of the capitalist mode of production in particular are integrated if a thorough understanding of the issue is pursued. Otherwise a mutilated understanding of the 
Anthropocene is obtained and the practical measures to confront this major threat will fail. Yet the research for a GSSP for the Anthropocene might have been triggered from outside stratigraphy, it has been undertaken strictly following stratigraphic procedures that have led to identify a number of potential stratotype sections and stratigraphic markers as required by the ICC/GTS rules (Waters et al., 2018). In this regard, there is not any difference between, say, the Oxygenian Period proposed for the Proterozoic based on the atmosphere oxygenation caused by the metabolic activity of cyanobacteria (Alterman et al., 2012) and the Anthropocene Epoch as proposed by the AWG. The only difference is that the sociometabolic activity of humans depends on the kind of social organization -a much more complex topic than the metabolism of any bacteria (Soriano, 2018a)- and that humanity is experiencing the major Earth change of the Anthropocene as a conscious and collective social being and in real time.

The inductive versus deductive dichotomy of science and hence of geology is a false debate based on some epistemic misunderstandings. The traditional dualism of induction and deduction has been long transcended from a dialectic and materialist view, in which both are seen as inseparable moments of any scientific understanding of reality (Ilyenkov, 1982). Shortly, an inductive understanding based on empirical facts is impossible in the lack of conceptualizations forming a theoretical framework obtained by deduction, and a deductive understanding in the lack of induction based on empirical evidence is equally impossible (Ilyenkov, 1982; Soriano, 2018b). When a geologist collect samples from a dike in order to obtain the Anisotropy of Magnetic Susceptibility (AMS) to infer magma flow relies on a theoretical background that determines the sampling strategy to get the expected results. If the same geologist samples a sedimentary succession to get the magnetostratigraphic profile the sampling strategy is different and it is determined by the theoretical concepts of magnetostratigraphy and sedimentology. When Earth scientists sample stratigraphic sections or other palaeoenvironmental archives looking for possible candidates to host a GSSP for the Anthropocene their target and expected results are determined by the theoretical background of Earth System science, geology, stratigraphy and by the understanding of the productive processes in modern society. For instance, earth scientists are not going to look for DDT signatures in a stratigraphic horizon of the XIX century or Neolithic times. The examples above illustrate how scientific knowledge proceeds: a deductive conceptual background is needed to obtain empirical data that, in turn, will be used to modify the theoretical background by inductive rationale. Actually, these examples illustrate the teleological character of scientific research understood as intellectual labour, a teleological character that is immanent to the ICC and GTS too, as shown by their iterative modifications across history based on deductiveinductive rationale. In this regard and for the case of the Anthropocene, it is irrelevant whether the conceptual framework of reference comes from Earth System science, stratigraphy or social science disciplines, actually, a transdisciplinary approach is needed for a comprehensive understanding of the issue.

Some critics draw attention to the fact that stratigraphy and hence the GTS deals with the geological past while the AWG proposal is focussed on the present and depends on future scenarios (Finney and Edwards, 2016; Rull, 2017). It should be noted that a mid- $20^{\text {th }}$ century age for the base of the Anthropocene documents about 70 years of stratigraphic record and that "[...] the case being made for the Anthropocene rest solely on evidence documented within existing strata that represent past events, as it must." (Zalasiewicz et al., 2017, p. 218, italics in the original). More broadly, the current trend of most scientific disciplines consists in the ability to predict future scenarios, and stratigraphy is not an exception. Weather forecasting, volcanic eruptions forecasting, simulation of depositional settings, financial market prediction and many other examples from both natural and social sciences show the increasing predictive character of science. Predictions may fail and some disciplines allow more reliable predictions than others based on their internal consistency and scientific development. But, overall, they are not speculations and they are based on the scientific deductive-inductive method shown above. Hence, the evolution of human population can be predicted for the nearest future provided some boundary conditions are maintained, namely, the capitalist production mode based on the reproduction of capital (Roser et al., 2019); the trajectory of the Earth System can be equally predicted by assuming similar conditions (Steffen et al., 2016, 2018); and astronomical tuning of sedimentary successions potentially allows cyclostratigraphic predictions provided some assumptions on sediment supply, depositional setting and other parameters are made.

Linked to the uncertain future of the Earth System evolution regarding the magnitude of planetary change and to its stratal record there is the debate on the hierarchical position of the Anthropocene in the GTS. This is a relatively independent issue from Anthropocene formalization. Provided a primary stratigraphic marker $-\mathrm{Pu}$ radionuclides in the AWG proposal- supported by suitable secondary markers are identified in a globally correlated stratotype section, the Anthropocene could be formalized as a Stage of the Holocene, in a similar way than most stages of the GTS, defined by a first fossil appearance. However, the AWG has defended the formalization of the Anthropocene as an Epoch because the stratigraphic signatures of the Anthropocene indicate a new Earth System state with 
different conditions than those prevailing during the Holocene Epoch. This means that the magnitude, rate and global signature of the Anhtropocene change are about the same scale than the scale represented by the onset of the Holocene. As noted by Zalasiewicz et al. (2019), this would leave open the option to define stages and other subunits of the Anthropocene Epoch. Accordingly, it is here launched the proposal to define a Stage of the Anthropocene Epoch named Capitalian with the same GSSP boundary than the Anthropocene (Fig. 2). In this way, the mechanism underlying the Anthropocene change would be accurately identified and the GTS would provide a true comprehensive understanding of the Earth history that fully includes humans and the specific socioeconomic organization causing the stratigraphic signature that defines such GSSP boundary.

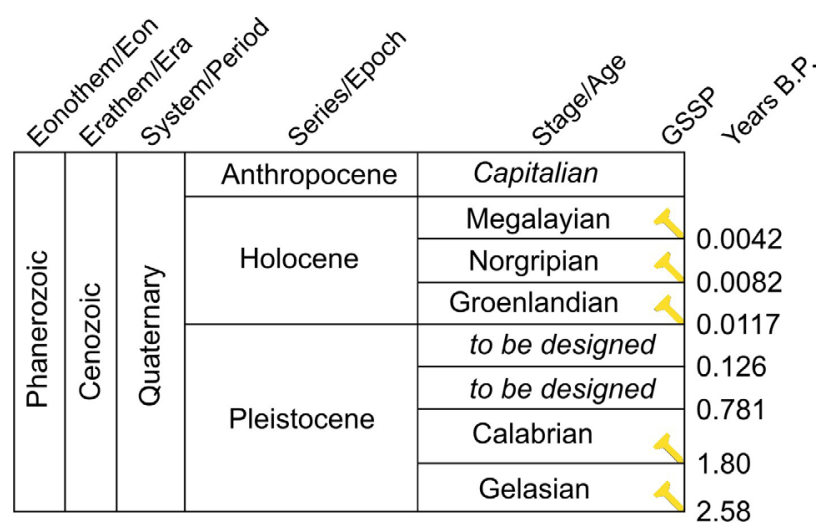

FIGURE 2. Proposal to formalize the Anthropocene as an Epoch of the Geological Time Scale and Capitalian as a Stage (modified from Zalasiewicz et al., 2017).

\section{CONCLUSIONS}

The GTS is an agreed convention aimed to furnish a standardize tool where the events of the Earth history can be referred in linear time as they are recorded in rocks. The AWG proposal to formalize the Anthropocene is rigorous and scientifically sounded and does not differ, essentially, from the approach followed to formalize other units of the GTS. Apparently, this proposal meets the requirements for GSSP definition and age calibration settled by the International Commission of Stratigraphy. The Anthropocene as proposed by the AWG marks the onset of an Earth transformation of unprecedented scale in human history as it is recorded in strata. Such transformation is empirically correlated to the capitalist mode of production and, more important, scientifically deduced to be immanent to the reproduction of capital. Hence, if the Anthropocene is defined as an Epoch, it is justified to define a Stage named Capitalian with the same lower boundary than the Anthropocene.
Rejection of the Anthropocene as a unit of the GTS is certainly a likely scenario as has been the case for other units submitted to formalization - see Tarentian in Late Pleistocene for example (Ogg et al., 2016). In those cases, research usually keeps going on in order to present more suitable proposals. For example, formalization of the Holocene took nearly 30 years of research (Walker et al., 2015). Regardless of the Anthropocene formalization, the stratigraphic signals of the planetary change will keep recording in rocks and quite likely more stratigraphic proxies and deposits will be found as scientific research on the Anthropocene proceeds and as long as society keeps on reproducing under the capitalist mode of production. However, if the proposal to formalize the Anthropocene meets the requirements of the GTS, as it seems, but it is not formalized, the GTS will not properly address the ongoing major Earth change and its stratal expression.

\section{ACKNOWLEDGMENTS}

Insightful comments by Frank Oldfield have greatly contributed to improve an earlier version of this manuscript.

\section{REFERENCES}

Altermann, W., Hoffman, P.F, Kasting, J.F., Nutman, A.P., Pirajno, F, Beard, B.L., Johnson, C.K., Melezhik, V.A., Papineau, D., 2012. The Precambrian: the Archean and Proterozoic Eons. In: Gradstein, FM., Ogg, J.G., Schmitz, M.D., Ogg, G.M. (eds.). The Geologic Time Scale 2012. Oxford, Elsevier, 300-365.

Angus, I., 2016. Facing the anthropocene: fossil capitalism and the crisis of the earth system. New York, Monthly Review, 280pp.

Autin, W.J., Holbrook, J.M., 2012a. Is the Anthropocene an issue of stratigraphy or pop culture? GSA Today, 22, 60-61.

Autin, W.J., Holbrook, J.M., 2012b. Reply. Reply to Jan Zalasiewicz et al. on Response to Autin and Holbrock "Is the Anthropocene an issue of stratigraphy or pop culture?" GSA Today, 22, e23.

Barnosky, A.D., Matzke, N., Tomiya, S., Wogan, G.O.U., Swartz, B., Quental, T.B., Marshall, C., McGuire, J.L., Lindsey, E.L., Maguire, K.C., Mersey, B., Ferrer, E.A., 2011. Has the Earth's sixth mass extinction already arrived? Nature, 471, 51-57.

Braje, T., 2016. Evaluating the Anthropocene: Is there something useful about a geological epoch of humans? Antiquity, 90, 504-512. DOI: 10.15184/aqy.2016.32

Ceballos, G, Ehrlich, P.R., Barnosky, A.D., García, A., Pringle, R.M., Palmer, T.M., 2015. Accelerated modern humaninduced species losses: Entering the sixth mass extinction. Science Advances, 1, e1400253.

Chen, X., 2017. The Ecological Crisis and the Logic of Capital. Leiden, Brill, 590pp. DOI: https://doi. org/10.1163/9789004356009 
Crutzen, P.J., Stoermer, E.F, 2000. The Anthropocene. Global Change Newsletter, 41, 17-18.

Delasalla, D.A., Goldstein, M.I. (eds.), 2018. Encyclopedia of the Anthropocene. Oxford, Elsevier, 2280pp.

Finney, S., Edwards, L., 2016. The "Anthropocene" Epoch: Scientific decision or political statement? GSA Today, 26, 4-10.

Gradstein, F.M., 2012. Introduction. In: Gradstein, FM., Ogg, J.G., Schmitz, M.D., Ogg, G.M. (eds.). The Geologic Time Scale 2012. Oxford, Elsevier, 1-29.

Gradstein, FM., Ogg, J.G., 2012. The Chronostratigraphic Scale. In: Gradstein, FM., Ogg, J.G., Schmitz, M.D., Ogg, G.M. (eds.). The Geologic Time Scale 2012.Oxford, Elsevier, 31-42.

Gradstein, FM., Ogg, J.G., Hilgen, FJ., 2012. On the Geological Time Scale. Newsletter on Stratigraphy, 45, 171-188.

Harland, W.B., Armonstrong, R.L., Cox, A.V., Craig, L.E., Smith, A.G., Smith, D.G., 1990. A geologic time scale 1989. Cambridge, University Press, 263pp.

Hilgen, FG., Brinkhuis, H., Zachariasse, W.J., 2006. Unit stratotypes for global stages: The Neogene perspective. Earth Science Reviews, 74, 113-125.

Ilyenkov, E., 1982. The Dialectics of the Abstract and the Concret in Marx's Capital. Progress Publishers. Last accessed: February 2020. Available at: https://www.marxists.org/archive/ilyenkov/ works/abstract/index.htm

Klein, G.D., 2015. The "Anthropocene": What is its geological utility (Answer: it has none!). Episodes, 38, 218.

Malm, A., Hornborg, A., 2014. The geology of mankind? A critique of the Anthropocene narrative. The Anthropocene Review, 1, 62-69.

Malm, A., 2016. Fossil Capital: The Rise of Steam Power and the Roots of Global Warming. London, Verso, 496pp.

Mészáros, I., 2008. The Challenge and Burden of Historical Time: Socialism in the Twenty-First Century. New York, Monthly Review Press, 480pp.

Ogg, J.G., Ogg, G.M., Gradstein, FM., 2016. Quaternary. In: Ogg, J.G., Ogg, G.M., Gradstein, FM. (eds.). A Concise Geologic Time Scale. Oxford, Elsevier, 211-226.

Oldfield, F, Steffen, W., 2014. Anthropogenic climate change and the nature of Earth System science. Anthropocene Review, 1, 70-75.

Rockström, J., Steffen, W., Noone, K., Persson, Å., Chapin III, F.S., Lambin, E.F., Lenton, T.M., Scheffer, M., Folke, C., Schellnhuber, H.J., Nykvist, B., de Wit, C.A., Hughes, T., Van der Leeuw, S., Rodhe, H., Sörlin, S., Snyder, P.K., Costanza, R., Svedin, U., Falkenmark, M., Karlberg, L., Corell, R.W, Fabry, V.J., Hansen, J., Walker, B., Liverman, D., Richardson, K., Crutzen, P., Foley, J.A., 2009. A safe operating space for humanity. Nature, 461, 472-475.

Roser, M., Ritchie, H., Ortiz-Ospina, E., 2019. World Population Growth. Published online at: OurWorldInData.org. Last accessed: February 2020. Available at: https://ourworldindata. org/world-population-growth

Rull, V., 2017. The "Anthropocene": neglects, misconceptions, and possible futures. EMBO reports, 18, 1056-1060.
Rull, V., 2018. What If the 'Anthropocene' Is Not Formalized as a New Geological Series/Epoch? Quaternary, 1, 24.

Soriano, C., 2018a. The Anthropocene and the production and reproduction of capital. The Anthropocene Review, 5, 202-213.

Soriano, C., 2018b. On the theoretical approaches to the Anthropocene challenge. The Anthropocene Review, 5, 214-218.

Sprain, C.J., Renne, P.R., Vanderkluysen, L., Pande, K., Self, S., Mittal, T., 2019. The eruptive tempo of Deccan volcanism in relation to the Cretaceous-Paleogene boundary. Science, 363, 866-870.

Steffen, W., Broadgate, W., Deutsch, L., Gaffney, O., Ludwig, C., 2015. The trajectory of the Anthropocene: The Great Acceleration. The Anthropocene Review, 2, 81-98.

Steffen, W., Leinfelder, R., Zalasiewicz, J., Waters, C.N., Williams, M., Summerhayes, C., Barnosky, A.D., Cearreta, A., Crutzen, P., Edgeworth, M., Ellis, E.C., Fairchild, I.J., Galuszka, A., Grinevald, J., Haywood, A., Ivar do Sul, J., Jeandel, C., McNeill, J.R., Odada, E., Oreskes, N., Revkin, A., Richter, D. de B., Syvitski, J., Vidas, D., Wagreich, M., Wing, S.L., Wolfe, A.P., Schellnhuber, H.J., 2016. Stratigraphic and Earth System approaches to defining the Anthropocene. Earth's Future, 4, 324-345.

Steffen, W., Rockström, J., Richardson, K., Lenton, T.M., Folke, C., Liverman, D., Summerhayes, C.P., Barnosky, A.D., Cornell, S.E., Crucifix, M., Donges, J.F., Fetzer, I., Lade, S.J., Scheffer, M., Winkelmann, R., Schellnhuber, H.J., 2018. Trajectories of the Earth System in the Anthropocene. PNAS, 115, 8252-8259.

Visconti, G., 2104. Anthropocene: another academic invention? Rendiconti Lincei Science Fisiche e Naturali, 25, 381-392.

Walker, M., Gibbard, P., Lowe, J. 2015. Comment on "When did the Anthropocene begin? A mid-twentieth century boundary is stratigraphically optimal" by Jan Zalasiewicz et al. (2015), Quaternary International, 383, 196-203. Quaternary International, 383, 204-207.

Waters, C.N., Zalasiewicz, J., Summerhayes, C., Barnosky, A.D, Poirier, C., Galuszka, A., Cearreta, A., Edgeworth, M., Ellis, E.C., Jeandel, C., Leinfelder, R., McNeill, J.R., Richter, D. de B., Steffen, W., Syvitski, J., Vidas, D., Wagreich, M., Williams, M., Zhisheng, A., Grinevald, J., Odada, E., Oreskes, N., Wolfe, A.P., 2016. The Anthropocene is functionally and stratigraphically distinct from the Holocene. Science, 351, aad2622, 1-10

Waters, C.N., Summerhayes, C.P., Rose, N.L., Shotyk, W., Head, M.J., Williams, M., Barnosky, A., Leinfelder, R., Galuszka, A., Gradstein, F, Mcneil, J., Poirier, C., Zalasiewicz, J., Fairchild, I., Loader, N.J., Cearreta, A., Syvitski, J.P., Wagreich, M., Zhisheng, C., Ivar do Sul, J.A., Steffen, W., Wing, S.L., Edgeworth, M., 2018. Global Boundary Stratotype Section and Point (GSSP) for the Anthropocene Series: Where and how to look for potential candidates. Earth Science Reviews, 178, 379-429.

Zalasiewicz, J., Cearreta, A., Crutzen, P., Ellis, E., Ellis, E., Grinevald, J., McNeill, J., Poirier, C., Price, S., Richter, D., 
Scholes, M., Steffen, W., Vidas, D., Waters, C., Williams, M., Wolfeet, A.P., 2012. Response to Autin and Holbrook on "Is the Anthopocene an issue of stratigraphy or pop culture?" GSA Today, 22, e21-e22.

Zalasiewicz, J., Waters, C.N., Wolfe, A.P., Barnosky, A.D., Cearreta, A., Edgeworth, M., Ellis, E.C., Fairchild, I.J., Gradstein, FM., Grinevald, J., Haff, P., Head, M.J., Ivar do Sul, J.A. Jeandel, C., Leinfelder, R., McNeill, J.R., Oreskes, N., Poirier, C., Revkin, A., Richter, D. de B., Steffen, W., Summerhayes, C., Syvitski, J.P.M., Vidas, D., Wagreich, M., Wing, S., Williams, M., 2016. Comment. Finney \& Edwards Article. GSA Today, 27, e36-e37.

Zalasiewicz, J., Waters, C.N., Wolfe, A.P., Barnosky, A.D., Cearreta, A., Edgeworth, M., Ellis, E.C., Fairchild, I.J., Gradstein, FM., Grinevald, J., Haff, P., Head, M.J., Ivar do Sul, J.A., Jeandel, C., Leinfelder, R., McNeill, J.R., Oreskes, N., Poirier, C., Revkin, A., Richter, D. de B., Steffen, W., Summerhayes, C., Syvitski,
J.P.M., Vidas, D., Wagreich, M., Wing, S., Williams, M., 2017. Making the case for a formal Anthropocene Epoch: an analysis of ongoing critiques. Newsletter on Stratigraphy, 50, 205-226.

Zalasiewicz, J., Waters, C., Head, M., Steffen, W., Syvitski, J., Vidas, D., Summerhayes, C., Williams, M., 2018. The geological and Earth System reality of the Anthropocene: reply to Bauer, A.M., Ellis, E.C., the Anthropocene divide: Obscuring understanding of social-environmental change. Current Anthropology, 59, 220-223.

Zalasiewicz, J., Waters, C.N., Head, M.J., Poirier, C., Summerhayes, C.P., Leinfelder, R., Grinevald, J., Steffen, W., Syvitski, J., Haff, P., McNeill, J.R., Wagreich, M., Fairchild, I.J., Richter, D.D., Vidas, D., Williams, M., Barnosky, A.D., Cearreta, A., 2019. A formal Anthropocene is compatible with but distinct from its diachronous anthropogenic counterparts: a response to W.F Ruddiman's three flaws in defining a formal Anthropocene. Progress in Physical Geography, 43, 319-333.

Manuscript received July 2019;

revision accepted January 2020;

published Online April 2020. 